УДК 340.12

DOI https://doi.org/10.32849/2663-5313/2020.7.46

\title{
Вікторія Корнієнко,
}

аспірант відділу теорії держави і права

Інституту держави і права імені В. М. Кореиького

Національної академії наук Украйни

\section{ВИСНОВОК ПРАВОВОЇ ЕКСПЕРТИЗИ: ТЕОРЕТИКО-ПРАВОВІ АСПЕКТИ}

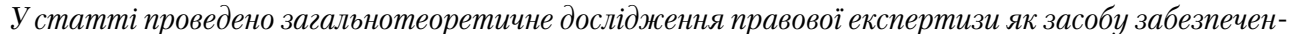
ня якості нормативно-правових актів. Нині такий важливий етап у правотворчому процесі, як правова експертиза, досліджується фрагментарно та потребує подальших наукових досліджень.

Окрім того, досліджено роль висновку експерта як результату проведення правової експертизи проєкту нормативно-правового акта. Зазначено, що питання щодо сутності поняття «висновок експерта» досліджували такі вчені, як: Л.Л. Богачова, В.О. Бутенко, Т.О. Дідич, З.А. Загиней, О Г. Мінкова, М.С. Мочульська, Ю.М. Перерва, Г.В. Рибікова, В.М. Тернавська, Н.В. Філик, В.Д. Юрчишин та інші.

Виокремлено позииї науковиів щодо таких понять, як «правова експертиза» та «висновок експерта». Окремо надано власне бачення вказаних юридичних категорій.

Визначено, що правова експертиза проєкту нормативно-правового акта - ие особливий етап нормопроєктної діяльності, що здійснюється спещіально уповноваженою особою, фахівщем (експертом), який має спеціальні знання та в результаті якої надається аргументований висновок щодо проєкту нормативно-правового акта.

Зазначено, що висновок правової експертизи - ие результат розумової та логічної діяльності суб'єкта проведення правової експертизи (експерта), в якому відображено всі необхідні відомості щодо об'єкта дослідження правової експертизи, який відповідає на всі поставлені на початку проведення правової експертизи питання, має письмовий характер, містить остаточну, вмотивовану думку експертів про прийнятність чи недоцільність прийняття проєкту нормативно-правового акта або подальшого функиіонування чинного акта.

Проведено аналіз критеріїв і вимог до нормативно-правового акта. Досліджено завдання правової експертизи та зауважено, що одним із ї̈ основних иілей є оцінка (концептуальна, системно-юридична оцінка та юридико-технічна), результатом якого виступає експертний висновок.

Розкрито характер висновку правової експертизи проєкту нормативно-правового акта, а також проаналізовано його сутність. Виокремлено структуру експертного висновку, враховуючи тендениї розвитку сучасної правової думки.

Ключові слова: нормопроєктна діяльність, проєкт, нормативно-правовий акт, оцінка, якість, експертна діяльність.

Постановка проблеми. Нині для забезпечення належного рівня якості законодавства виникає необхідність проведення правової експертизи нормативно-правових актів на стадії нормопроєктування. Для проведення цього виду експертизи виникає потреба в застосуванні різних методів наукового дослідження, а отже, в залученні до вказаного процесу виключно висококваліфікованих фахівців, які можуть надати об'єктивний і вмотивований висновок щодо проєкту, який досліджується.

Аналіз останніх джерел і публікацій. Питання щодо сутності поняття «висновок експерта» досліджували такі вчені, як: Л.Л. Богачова, В.О. Бутенко, Т.О. Дідич, З.А. Загиней, О.Г. Мінкова, М.Є. Мочульська, Ю.М. Перерва, Г.В. Рибікова, В.М. Тернавська, Н.В. Філик, В.Д. Юрчишин та інші.
Мета статті. Основними завданнями статті $€$ визначення поняття та сутності висновку експерта під час проведення правової експертизи проєкту нормативно-правового акта. При цьому не менш важливим є також дослідження питання правової експертизи.

Виклад основного матеріалу. Насамперед для правильного розуміння поняття «висновок експерта» необхідно дати визначення поняття «правова експертиза».

Наприклад, деякі вчені під правовою експертизою розуміють дослідження, що проводиться експертом на підставі рішення або за дорученням уповноважених на те осіб, або без такого, але через пряму вказівку нормативно-правових актів, засноване на застосуванні спеціальних знань із метою 
використання його результатів в юридичній діяльності та яке полягає у наданні документа у формі висновку цієї експертизи [13, c. 62].

У більш широкому значенні правову експертизу можна розглядати як діяльність спеціально уповноважених осіб, які мають спеціальні знання, необхідні для розв'язання питань, що виникають під час здійснення будьякого виду юридичної практики [6, с. 271].

Окрім того, варто зауважити, що експертне дослідження є діяльністю компетентного суб'єкта (експерта), який має спеціальні знання щодо дослідження та розв'язання певного питання, здійснює таке дослідження відповідно до чинного законодавства, а результати такого дослідження мають юридичне значення [7, с. 64].

На думку автора, правова експертиза являє собою особливий етап нормопроєктної діяльності, що здійснюється спеціально уповноваженою особою, фахівцем (експертом), який має спеціальні знання, та в результаті якої надається аргументований висновок щодо проєкту нормативно-правового акта.

Окрім того, варто зазначити, що метою правової експертизи є оцінка відповідності проєкту нормативно-правового акта певним правовим вимогам.

До переліку таких критеріїв деякі науковці відносять, зокрема: обгрунтованість застосування закону, відповідність положень нормам Конституції України, дотримання правил законодавчої техніки, дієвість - розгляд завдань, що розв'язуються в конкретній сфері, та відповідність результатів поставленій меті, цілям, культурним особливостям і надбанням держави [9, с. 167].

Інша група вчених також визначає параметри іншого роду. Наприклад, Л.Л. Богачова до вимог, яким має відповідати нормативноправовий акт, відносить такі: реквізити, структуру, офіційне оприлюднення, а також державну реєстрацію [4, с. 17-18].

На думку автора, до переліку вимог, які застосовуються до нормативно-правового акта, варто віднести чітко визначену структуру, регламентовану процедуру нормопроєктування, а також доцільність, ефективність, об'єктивність， своєчасність，узгодженість та якість.

Деякі науковці наголошують, що саме правова експертиза має дати оцінку відповідності проєкту нормативно-правового акта сучасним досягненням вітчизняної та зарубіжної правової науки та юридичної практики, узгодженості положень проєкту акта іншим правовим актам, визначити його соціальну та економічну доцільність, наслідки його реалізації [11, с. 276].
Експертиза має відповісти на запитання: права яких суб'єктів правовідносин обмежуються та в якому обсязі; права яких суб'єктів реалізуються найкращим чином, тобто захищаються максимально; які нормативно-правові акти потребують змін [10, с. 49].

Такою оцінкою в процесі проведення експертизи проєкту нормативно-правового акта $\epsilon$ експертний висновок.

Окремі вчені наголошують, що завдяки проведенню правової експертизи є змога дістати об'єктивний, незалежний і неупереджений висновок, який сприяє вдосконаленню процесу нормопроєктування [5, с. 14].

Загалом, у тлумачному словнику під висновком розуміють остаточну думку про що-небудь, логічний підсумок, зроблений на основі спостережень, міркувань або розгляду певних фактів.

Зі свого боку висновок експерта - це документ, що містить результат проведеної експертизи [1, с. 152].

Варто виокремити позицію науковців, які зазначають, що експертний висновок $€$ основною метою експертної діяльності уповноважених суб'єктів і характеризує цінність і результативність самої експертної діяльності. Відповідно, статус і значення експертного висновку набувають великого значення для досягнення відповідного правового ефекту від проведення експертного дослідження проєктів юридичних документів [2, с. 13].

Інша група вчених розглядає поняття «висновок правової експертизи» як результат проведення експертного дослідження нормативно-правових актів на підставі визначеної методики, що містить чіткі відповіді на питання відповідності об'єкта експертизи необхідним юридичним критеріям якості та пропозиції щодо усунення виявлених недоліків [12, с. 62]. Вказану позицію підтримують й інші вчені [3, с. 10].

Вказане твердження доповнює також позиція дослідників, які зазначають, що висновок правової експертизи являє собою письмовий документ, який приймається уповноваженою особою або групою осіб за результатами дослідження проєкту юридичного документа та відображає інформаційний матеріал щодо якісних правових характеристик документа й шляхів усунення виявлених у ньому недоліків [2, с. 13].

Більш широке тлумачення щодо характеру висновку експерта можна знайти в нормативно-правовій базі.

Наприклад, згідно з Методичними рекомендаціями щодо проведення правової експертизи проєктів нормативно-правових актів, експертний висновок має відповісти на 
низку запитань, а також повинен бути побудований у результаті узагальнення окремих оцінок, до яких належить:

- насамперед, концептуальна оцінка проєкту нормативно-правового акта, що передбачає визначення сфери суспільних відносин, які він має регулювати, і відповідної галузі права, до якої він належить, а також предмета й методу регулювання конкретного фрагменту цих відносин і засобів впливу на поведінку їхніх учасників;

- наступною $€$ системно-юридична оцінка, яка передбачає визначення ступеня відповідності нормативних приписів положенням чинних міжнародних договорів, згода на обов'язковість яких надана Верховною Радою України та які стосуються предмета регулювання цього проєкту нормативно-правового акта [14];

- варто зазначити, що одним із елементів системно-юридичної $є$ порівняльноюридична оцінка, яка полягає в зіставленні характеру нормативного регулювання тих самих або аналогічних питань у минулому Окрім того, іншим елементом виступає міжнародно-юридична оцінка, яка покликана ототожнити проєкт нормативно-правового акта 3 відповідними за тематикою чинними міжнародними договорами 3 метою виявлення та усунення можливих суперечностей і неузгодженостей;

- і завершує цей перелік юридико-технічна оцінка, яка має на меті визначення ступеня його відповідності усталеним правилам побудови та редакційно-лексичного оформлення нормативно-правових актів [14].

Загальна оцінка проєкту акта формулюється на основі оцінок за кожним із наведених вище блоків питань правової експертизи (концептуальна, системноюридична та юридико-технічна оцінки). Під час визначення загальної оцінки має враховуватися нерівнозначність оцінок за окремими блоками питань. Більший вплив на остаточний висновок щодо проєкту мають результати концептуальної та системно-юридичної оцінок, а їхній негативний характер може зумовити загальний висновок про необхідність відхилення проєкту нормативно-правового акта. Низька юридико-технічна оцінка може зумовити висновок про необхідність більш або менш значного змістового перероблення проєкту або внесення до нього редакційних змін [14].

Науковці також зазначають, що підготовлений висновок правової експертизи має зводитися до двох можливих варіантів:

1) позитивний висновок (нормативноправовий акт позитивно оцінюється i, за потреби, може містити певні умови щодо додаткового опрацювання недоліків юридичної техніки);

2) негативний висновок (нормативноправовий акт, реалізація якого суперечить вимогам чинного законодавства, а отже $€$ неприйнятним узагалі (за цих умов чи в цей час), і,відповідно, такий акт не може бути прийнятий або має бути скасований повністю або частково [12, с. 62].

Вважаємо, що для того, щоб висновок експерта був більш аргументований, варто до позитивного і негативного додати позитивний висновок з умовою. Суть вказаного виду висновку полягає в тому, що проєкт нормативно-правого акта, який підлягає експертному дослідженню, містить незначні відмінності щодо чинних нормативно-правових актів. Також вказаний висновок має містити рекомендації з усунення вказаних невідповідностей, що дасть змогу надалі прийняти досліджуваний проєкт.

Окрема група науковців також наголошує, що нормативно-правовий акт не може бути внесеним до відповідного реєстру на підставі висновку експертизи (якщо нормативно-правовий акт не отримав позитивного висновку експертизи, він повертається до суб'єкта правотворчості та не набирає чинності) [12, с. 63].

Окрім того, варто зазначити, що висновок експерта має чітко регламентовану структуру. Зокрема, експертний висновок складається зі вступної, аналітичної та підсумкової частин.

У вступній частині визначається об'єкт і предмет правової експертизи, наводяться дані про експерта або групу експертів, які проводили експертизу.

Аналітична частина повинна містити обгрунтовані зауваження до тексту проєкту нормативно-правового акта відповідно до кожного з наведених блоків питань правової експертизи, а також пропозиції щодо усунення виявлених недоліків.

У підсумковій частині формулюються концептуальна, системно-юридична та юридико-технічна оцінки проєкту нормативноправового акта, а також його загальна оцінка [14].

Варто також виокремити думку О.Г. Мінкової, яка зазначає, що форма і структура експертного висновку можуть варіюватися залежно від виду експертизи та їі виконавців $[3$, c. 10$]$.

Загалом, сутність і значення експертного висновку полягає в тому, що він:

- відображає процес і результат проведення експертного дослідження проєкту юридичного документа; 
- містить узагальнені думки експертів щодо якості проєкту юридичного документа, недоліків, які в ньому виявлено, та засобів їх усунення перед тим, як внести на розгляд до правотворчого органу;

- має внутрішню будову, що складається з описової, резолятивної та рекомендаційної частин;

- надає змогу як перевірити якість проєкту юридичного документа, так і рекомендувати шляхи усунення виявлених у ньому недоліків;

- відображає рівень роботи суб'єктів нормопроєктування;

- приймається в певному юридично закріпленому порядку;

- має певний статус, що передбачений чинним законодавством;

- здійснюється у правовій сфері та відображає певний рівень правової підготовки проєкту юридичного документа;

- приймається уповноваженими суб'єктами відповідно до їхньої компетенції, що встановлена чинним законодавством [2, с. 13].

Зазначене дає можливість окреслити особливості, властиві саме висновку експерта як результату проведення правової експертизи проєкту нормально-правового акта.

Доцільно також зазначити, що вмотивований експертний висновок може виступати прецедентом у правотворчій діяльності для уникнення у майбутньому недоліків під час створення проєкту нормативно-правового акта в тій чи іншій сфері.

Окрім того, часто виникає питання щодо статусу висновків наукових правових експертиз.

Деякі вчені зазначають, що в Україні такі висновки мають допоміжний, рекомендаційний характер, що спричиняє зниження ролі та ваги правової науки загалом і правової доктрини як їі частини у процесі створення та застосування правових приписів. Видається, що це є однією з причин низької якості та неефективності частини нормативно-правових актів.

Однак мають місце непоодинокі випадки застосування висновків наукових правових експертиз у процесі створення правових приписів і здійснення правосуддя. При цьому виникає необхідність удосконалення законодавчого регулювання проведення наукових правових експертиз та врахування їхніх висновків, адже саме це є передумовою прийняття науково обгрунтованих правових приписів, заповнення прогалин у правовому регулюванні суспільних відносин та усунення суперечностей у системі нормативноправових актів. [8, с. 62-63].

\section{Висновки}

Узагальнивши різні підходи до розуміння досліджуваного питання, варто підсумувати, що поняття «висновок правової експертизи нормативно-правових актів» являе собою результат розумової та логічної діяльності суб'єкта проведення правової експертизи (експерта), в якому відображено всі необхідні відомості щодо об'єкта дослідження правової експертизи, який відповідає на всі поставлені на початку проведення правової експертизи питання, має письмовий характер, містить остаточну, вмотивовану думку експертів про прийнятність чи недоцільність прийняття проєкту нормативно-правового акта або подальшого функціонування чинного акта.

\section{Список використаних джерел:}

1. Великий тлумачний словник сучасної української мови (з дод. і допов.) / уклад. і голов. ред. В.Т. Бусел. Київ ; Ірпінь : ВТФ «Перун», 2005 $1728 \mathrm{c}$.

2. Бутенко В.О. Феноменологічні, методологічні та практичні основи правової експертизи юридичних документів : автореф. дис. ... канд. юрид. наук : 12.00.01. Київ, 2011. 20 с

3. Мінкова О.Г. Експертне забезпечення правотворчості в Україні : теоретико-правова характеристика : автореф. дис. ... канд. юрид. наук 12.00.01. Харків, 2016. 21 с

4. Богачова Л.Л. Вимоги до підзаконного нормативно-правового акта як офіційного документа. Науковий вісник Міжнародного гуманітарного університету. Серія : Юриспрудениія 2017. Вип. 29 (1). С. 16-19.

5. Дідич Т.О. Правова експертиза проектів нормативно-правових актів як необхідна складова нормопроектування: ознаки, методи, функції та завдання. Часопис Київського університету права. 2003. № 3. С. $14-17$.

6. Загиней 3.А. Правова експертиза як засіб виявлення недоліків тексту кримінального закону України: загальнотеоретичний аспект. Часопис Київського університету права. 2013. № 4. C. 270-273.

7. Манько Д.Г. Технології проведення правової експертизи юридичних документів. Наукові записки Міжнародного гуманітар ного університету : збірник. Одеса : Фенікс, 2016. Вип. 25. С. 63-67.

8. Мочульська М.Є. Правова доктрина та наукова правова експертиза: взаємодія в сучасних умовах. Науковий вісник Львівського державного університету внутрішніх справ. 2012. Вип. 4. С. 55-64.

9. Перерва Ю.М. Деякі питання експертизи законопроектів в Україні. Вісник Харківського національного університету внутрішніх справ. 2008. № 42. C. 166-171. 
10. Рибікова Г.В. Місце правової експертизи нормативно-правових актів в процесі правотворчості. Юридичний вісник. Повітряне $i$ космічне право. 2008. Вип. 1 (6). C. 48-52.

11. Тернавська В.М. Місце і роль правового моніторингу та правової експертизи в системі засобів правової політики. Альманах права. 2019. Вип. 10. С. 274-279.

12. Філик Н.В., Рибікова Г.В. Процедура проведення правової експертизи нормативно-пра- вових актів в Україні. Юридичний вісник. 2017. № 2 (43). C. 59-64.

13. Юрчишин В.Д. Поняття та ознаки правової експертизи проектів нормативно-правових актів. Держава і право. 2011. № 51. С. 57-63.

14. Методичні рекомендації щодо проведення правової експертизи проектів нормативно-правових : схвалено Постановою колегії Міністерства юстиції України від 21 листопада 2000 р. № 41. URL: http://zakon1.rada.gov.ua/cgi-bin/laws/main. cgi?Nreg=va041323-00.

Victoria Kornienko. Conclusion of legal expertise: theoretical and legal aspects

The article describes a general theoretical research of the legal expertise as a tool of ensuring the quality of normative legal act. Today, such an important stage in the law-making process as legal expertise is studied in fragments and requires further research.

In addition, the role of the expert's conclusion as a result of the legal expertise of the project of the normative legal act is investigated. It is noted that the question of the essence of the concept of "expert opinion" was studied by such scientists as: L. Bogachova, V Butenko, T. Didych, Z. Zaginey, O. Minkova, M. Mochulska, Y. Pererva, G. Rybikova, V. Ternavska, N. Filik, V. Yurchyshyn and others.

The positions of scientists on such concepts as "legal expertise" and "expert conclusion" are highlighted. The own vision of the specified legal categories is given separately.

It is determined that the legal expertise of the project of the normative legal act is a special stage of normative-project activity. It carried out by a specially authorized person, specialist (expert) who has special knowledge. As a result of which a reasoned conclusion on the project of the normative legal act is provided.

It is noted that the conclusion of the legal expertise is the result of mental and logical activities of the subject of legal expertise (expert). The expert reflects all the necessary information about the object of study of legal expertise, which answers all questions at the beginning of legal expertise. This conclusion has also a written character, contains the final, motivated opinion of experts on the admissibility or inexpediency of adopting a project of the normative legal act or further operation of the current act.

The analysis of criteria and requirements to the normative legal act is carried out. The tasks of legal expertise are studied, and it is noted that one of its main goals is the assessment (conceptual, system-legal assessment and legal-technical), the result of which is an expert opinion.

The nature of the conclusion of the legal expertise of the project of normative legal act is revealed. Its essence is also analyzed. The structure of the expert opinion is singled out, taking into account the tendencies of development of modern legal thought.

Key words: normative-project activity, project, normative legal act, assessment, quality, expert activity. 